\title{
Perbandingan Efek Fentanil dengan Ketamin terhadap Skor Pemulihan Pascaanestesi Umum Diukur dengan QoR-40 serta Perubahan Tekanan Darah dan Nadi pada Operasi Odontektomi
}

\author{
Adhitya Pratama, Erwin Pradian, Erias Erlangga \\ Departemen Anestesiologi dan Terapi Intensif \\ Fakultas Kedokteran Universitas Padjadjaran/RSUP Dr. Hasan Sadikin Bandung
}

\begin{abstract}
Abstrak
Penggunaan fentanil pada anestesi umum memiliki pengaruh terhadap pemulihan pascaoperasi dan penurunan hemodinamik saat induksi. Metode anestesi umum menggunakan analgetik nonopioid diharapkan meningkatkan kualitas pemulihan pascaoperasi. Pemberian ketamin dosis subanestesi memberi efek analgetik dengan efek samping minimal serta perubahan tekanan darah dan nadi lebih stabil. Tujuan penelitian ini membandingkan efek fentanil dengan ketamin terhadap kualitas pemulihan serta perubahan tekanan darah dan nadi saat induksi. Penelitian ini merupakan uji klinis tersamar ganda pada 30 pasien yang menjalani operasi odontektomi dengan anestesi umum di Rumah Sakit Umum Pusat Dr. Hasan Sadikin Bandung dari Januari-Maret 2020. Pasien dibagi menjadi 2 kelompok, yaitu kelompok ketamin, diinduksi menggunakan ketamin $0,5 \mathrm{mg} / \mathrm{kgBB}$ dan kelompok fentanil, diinduksi menggunakan fentanil 1,5 mcg/ $\mathrm{kgBB}$. Data dianalisis dengan uji-t tidak berpasangan, Uji Mann Whitney, dan Uji Kolmogorov-smirnov dengan nilai $p<0,05$ dianggap bermakna. Terdapat penurunan tekanan darah dan nadi yang signifikan $(p<0,05)$ di menit ke-1, 3, dan 5 pada grup fentanil. Penilaian QoR-40 pada kelompok ketamin memiliki angka lebih tinggi $(181,07 \pm 5,32)$ dibanding dengan kelompok fentanil $(176,60 \pm 2,59)$ secara bermakna $(p<0,05)$. Simpulan, skor pemulihan pascaanestesi umum dengan ketamin lebih tinggi dibanding dengan fentanil pada operasi odontektomi yang dinilai dengan QoR-40 dan ketamin dengan dosis subanestesi saat induksi menunjukkan hemodinamik yang lebih stabil dibanding dengan induksi menggunakan fentanil.
\end{abstract}

Kata kunci: Fentanil, ketamin, odontektomi, QoR-40, skor pemulihan pascaanestesi umum

\section{Comparison of Fentanyl and Ketamine's Effects on Post-General Anesthesia Recovery Scores Measured by QoR-40 and Changes in Blood Pressure and Pulse in Odontectomy Surgery}

\begin{abstract}
The use of fentanyl in general anesthesia has side effects that may prolong postoperative recovery and hemodynamic decline when induction. Methods of general anesthesia without fentanyl may improve the quality of postoperative recovery. Ketamine in subanesthetic doses has analgesic effects with minimal side effects and more stable blood pressure and pulse changes. This study aimed to compare fentanyl and ketamine's effects on quality of recovery and changes in blood pressure and pulse. This was a double-blinded clinical study in 30 patients with odontectomy under general anesthesia in Dr. Hasan Sadikin General Hospital from January-March 2020. Patients were divided into two groups, a ketamine group, induced using $0.5 \mathrm{mg} /$ kgBW ketamine, and a fentanyl group, induced using 1,5 mcg/kgBW fentanyl. Data were analyzed using the unpaired t-test, Mann Whitney, and Kolmogorov-Smirnov test, a p-value of $<0.05$ was considered significant. Values of QoR-40 in the ketamine group had a significantly $(\mathrm{p}<0.05)$ higher value $(181.07 \pm 5.32)$ compared to the fentanyl group $(176,60 \pm 2,59)$. In conclusion, the quality of post-general anesthesia recovery using ketamine is higher than fentanyl in odontectomy evaluated using QoR-40. Induction using subanesthetic doses of ketamine shows more stable hemodynamic than fentanyl.
\end{abstract}

Key words: Fentanyl, ketamine, odontectomy, QoR-40, recovery score post-general anesthesia

Korespondensi: Adhitya Pratama, dr., Departemen Anestesiologi dan Terapi Intensif Fakultas Kedokteran Universitas Padjadjaran/Rumah Sakit Dr. Hasan Sadikin Bandung, Jl. Pasteur No 38 Bandung 40161, Tlpn 022-2038285, Email adhitdut84@gmail.com 


\section{Pendahuluan}

Konsep yang diterapkan pada praktik anestesi umum adalah balance anaesthesia yang ditentukan oleh komponen trias anestesi, yaitu hipnotik, analgesia, dan relaksasi otot. ${ }^{1}$ Selama ini opioid paling sering digunakan sebagai analgesia pada anestesi umum. Opioid memiliki efek samping yang tidak diinginkan, seperti mual dan muntah pascaoperasi, pusing, hipoksia, konstipasi, kesulitan berkemih, delirium, dan depresi pernapasan. Komplikasi ini dapat menyebabkan waktu perawatan rumah sakit bertambah, peningkatan biaya perawatan, dan meningkatkan morbiditas serta mortalitas. Fentanil dapat menyebabkan penurunan hemodinamik saat induksi yang diakibatkan oleh bradikardia, venodilatasi, dan penurunan refleks simpatis. ${ }^{2}$

Ketamin pada dosis subanestesi merupakan salah satu obat yang dapat menggantikan opioid sebagai analgetik dengan efek samping minimal (halusinasi, mimpi buruk, distres pernapasan, dan mual muntah). ${ }^{3}$ Pada prosedur bedah singkat terbukti ketamin lebih baik dalam menjaga kestabilan hemodinamik dengan efek samping yang lebih minimal dibanding dengan fentanil. ${ }^{4}$

Odontektomi merupakan operasi yang paling banyak dilakukan pada operasi rongga mulut. Operasi pada pasien impaksi dengan anestesi umum membutuhkan perawatan yang singkat di rumah sakit, oleh karena itu dibutuhkan teknik anestesi dan obat-obatan yang memiliki efek samping seperti mual muntah, delirium, dan nyeri pada periode pascaanestesi yang minimal. ${ }^{5}$

Pemulihan pascaanestesi umum menjadi satu hal yang penting untuk dinilai sebagai hasil akhir pelayanan anestesi. Pemulihan pascaanestesi umum dinilai secara objektif dari kesadaran, tanda vital, beberapa efek samping seperti nyeri, mual, dan kesiapan untuk keluar dari ruang pemulihan serta ruang perawatan. Namun, hal-hal tersebut belum cukup menggambarkan pemulihan pascaanestesi umum secara komprehensif. Evaluating patient-reported outcomes (PROs) merupakan istilah yang berkembang pada pelayanan kesehatan saat ini. Pentingnya kualitas pemulihan bertujuan memperpendek masa perawatan, mengurangi biaya perawatan, menurunkan komplikasi, dan meningkatkan kepuasaan pasien. ${ }^{6}$

Instrumen QoR-40 merupakan kuesioner yang dikembangkan pada tahun 2000 di Australia. QoR-40 secara spesifik menilai kualitas pemulihan pascaanestesi umum dengan komprehensif tidak hanya dari aspek klinis, namun juga aspek-aspek yang memengaruhi kepuasan pasien terhadap pelayanan anestesi. Pertanyaan kuesioner Qor-40 mewakili semua aspek yang dianggap sebagai konsep kualitas pemulihan pascaanestesi, yaitu kenyamanan, perasaan, kemandirian fisik, dukungan terhadap pasien, dan nyeri. ${ }^{7,8}$

Tujuan penelitian ini adalah mengetahui skor kualitas pemulihan pascaanestesi umum serta perubahan tekanan darah dan nadi dengan ketamin dibanding dengan fentanil pada operasi odontektomi yang dinilai dengan QoR-40.

\section{Subjek dan Metode}

Penelitian ini mempergunakan metode eksperimental analitik komparatif kategorik numerik dengan desain double blind randomized clinical controlled trial. Subjek penelitian adalah pasien yang menjalani operasi odontektomi dengan anestesi umum di RSUP Dr. Hasan Sadikin Bandung. Pemilihan subjek penelitian berdasar atas kriteria inklusi, yaitu usia 18-65 tahun, status fisik American Society of Anesthesiologists (ASA) kategori III, pendidikan minimal Sekolah Menengah Atas atau sederajat. Kriteria eksklusi pada penelitian ini adalah pasien memiliki alergi obat anestesi dan pasien yang memiliki gangguan psikotik. Kriteria pengeluaran pada penelitian ini adalah terjadi reaksi obat yang tidak diduga sebelumnya, intubasi lebih dari $1 \mathrm{x}$, dan hemodinamik tidak stabil saat operasi.

Penentuan jumlah sampel menggunakan formula perhitungan besar sampel pada penelitian analitik komparatif kategorik numerik tidak berpasangan dan didapatkan 
jumlah sampel minimal 15 pasien untuk tiap-tiap kelompok. Pengambilan sampel dilakukan secara consecutive sampling dan dilakukan randomisasi subjek ke dalam dua kelompok penelitian dengan metode randomisasi blok permutasi. Subjek penelitian dibagi menjadi dua kelompok, yaitu kelompok fentanil mendapat fentanil 1,5 mcg/kgBB dan kelompok ketamin mendapat ketamin 0,5 mg/ kgBB untuk induksi. ${ }^{4}$ Penelitian dilaksanakan di RSUP Dr. Hasan Sadikin Bandung pada bulan Januari-Maret 2020 setelah mendapat persetujuan dari Komite Etik Penelitian Kesehatan Fakultas Kedokteran Universitas Padjdjaran/RSUP Dr. Hasan Sadikin Nomor LB.02.01/X.2.2.1/996/2020.

Prosedur penelitian dimulai dengan informed consent mengenai tindakan anestesi dan penelitian yang dilakukan. Pasien yang sesuai kriteria inklusi dan tidak termasuk kriteria eksklusi serta telah manandatangani persetujuan turut dalam penelitian (informed consent) dijadikan sebagai subjek penelitian. Pasien pada kedua kelompok dipuasakan selama 6 jam dengan pemberian cairan rumatan ringer laktat sebanyak $2 \mathrm{cc} / \mathrm{kgBB} /$ jam.

Setelah masuk ke kamar operasi, pasien dipasang alat untuk memantau tekanan darah noninvasif, elektrokardiogram, dan saturasi oksigen. Pasien kemudian dilakukan pemeriksaan tekanan darah, laju nadi, laju napas, serta saturasi untuk mengetahui hemodinamik awal. Kelompok $\mathrm{K}$ diberikan ketamin $0,5 \mathrm{mg} / \mathrm{kgBB}$ secara intravena dan kelompok $\mathrm{F}$ diberikan fentanil 1,5 mcg/ kgBB secara intravena, kemudian kedua kelompok tersebut diberikan propofol 2 $\mathrm{mg} / \mathrm{kgBB}$ i.v., atrakurium $0,5 \mathrm{mg} / \mathrm{kgBB}$ i.v. Obat-obatan hipnotik sedatif lain tidak ada

Tabel 1 Karateristik Subjek Penelitian

\begin{tabular}{|c|c|c|c|}
\hline \multirow[b]{2}{*}{ Variabel } & \multicolumn{2}{|c|}{ Kelompok } & \multirow[b]{2}{*}{ Nilai p } \\
\hline & $\begin{array}{c}\text { Ketamin } \\
(n=15)\end{array}$ & $\begin{array}{c}\text { Fentanil } \\
(n=15)\end{array}$ & \\
\hline \multicolumn{4}{|l|}{ Usia (tahun) } \\
\hline Mean \pm SD & $25,00 \pm 7,081$ & $2, .60 \pm 5,565$ & 0,267 \\
\hline \multicolumn{4}{|l|}{ Jenis kelamin } \\
\hline Laki-laki & 3 & 4 & 1,000 \\
\hline Perempuan & 12 & 11 & \\
\hline \multicolumn{4}{|l|}{ Tinggi badan $(\mathrm{cm})$} \\
\hline Mean \pm SD & $155,87 \pm 6,854$ & $157,47 \pm 8,935$ & 0,586 \\
\hline \multicolumn{4}{|l|}{ Berat badan (kg) } \\
\hline Mean \pm SD & $55,00 \pm 6,256$ & $56,87 \pm 7,180$ & 0,454 \\
\hline \multicolumn{4}{|l|}{ BMI $\left(\mathrm{kg} / \mathrm{m}^{2}\right)$} \\
\hline Mean \pm SD & $22,62 \pm 1,774$ & $22,95 \pm 2,418$ & 0,902 \\
\hline \multicolumn{4}{|l|}{ Lama operasi (menit) } \\
\hline Mean \pm SD & $89,67 \pm 23,488$ & $89,33 \pm 23,820$ & 0,670 \\
\hline \multicolumn{4}{|l|}{ Pendidikan } \\
\hline SMA & 9 & 7 & \\
\hline D3 & 1 & 1 & 0,999 \\
\hline S1 & 5 & 7 & \\
\hline
\end{tabular}

Keterangan: nilai kemaknaan berdasar atas nilai $\mathrm{p}<0,05$. Tanda* menunjukkan nilai $\mathrm{p}<0,05$ artinya signifikan atau bermakna secara statistik. 
tambahan. Kedalaman anestesi dijaga dengan gas Isoflurane dan gas $\mathrm{N}_{2} \mathrm{O}: \mathrm{O}_{2} \quad 50 \%$. Tiga puluh menit sebelum operasi selesai pasien diberikan bolus analgetik parasetamol 20 $\mathrm{mg} / \mathrm{kgBB}$ i.v. Selama operasi, tekanan darah dan laju nadi pasien dicatat pada menit ke1, 3, dan 5. Selanjutnya, pasien diberikan analgetik pascaoperasi dengan parasetamol $20 \mathrm{mg} / \mathrm{kgBB}$ i.v. tiap enam jam. Selama observasi, skala nyeri pasien diukur dengan menggunakan NRS yang dinilai pada saat di ruang pemulihan. Skala nyeri lebih dari atau sama dengan 4 diberikan rescue analgetik fentanil $25 \mu$ g i.v. yang dapat diulang tiap 15 menit hingga skala nyeri menurun hingga kurang dari 4. Tingkat kepuasan pasien dinilai dengan instrumen kuesioner QoR-40 pada saat 24 jam pascaoperasi di ruang rawat. Kuesioner ini didapatkan dengan mengambil intisari dari 50 pertanyaan yang berhubungan dengan pemulihan pascaanestesi dan bedah. Total skor dan skala QoR-40 diukur menggunakan skala Likert 5 poin, kemudian skor tiap-tiap individu dijumlahkan, minimum skor 40 poin (pemulihan sangat buruk) dan maksimal skor 200 poin (pemulihan sangat baik).

Uji statistik penelitian ini menggunakan uji t dan Uji Mann Whitney pada data numerik. Uji statistik pada data kategorik menggunakan uji chi-square dengan alternatif uji KolmogorovSmirnov. Kriteria kemaknaan ditentukan dengan dengan $\mathrm{p} \leq 0,05$ dianggap signifikan atau bermakna secara statistik. Data hasil penelitian dicatat dan diolah menggunakan program statistical product and service solution (SPSS) versi 24.0 for windows.

\section{Hasil}

Gambaran karakteristik subjek penelitian antara kelompok ketamin dan kelompok fentanil berdasa atas usia, jenis kelamin, tinggi badan, berat badan, BMI, lama operasi, dan tingkat pendidikan tidak berbeda signifikan ( $p>0,05$; Tabel 1).

Pada variabel tekanan darah sistole (TDS) 1 menit, TDS3 menit, dan TDS 5 menit didapatkan bahwa TDS rerata kelompok ketamin lebih tinggi dibanding dengan kelompok fentanil dengan perbedaan signifikan $(\mathrm{p}<0,05$; Tabel 2).

Pada variabel tekanan darah diastole (TDD) 3 menit dan TDD 5 menit didapatkan bahwa TDD rerata kelompok ketamin lebih tinggi dibanding dengan kelompok fentanil dengan perbedaan signifikan $(p<0,05$; Tabel 3$)$.

Tabel 2 Perbandingan Tekanan Darah Sistole pada Kedua Kelompok

\begin{tabular}{|c|c|c|c|}
\hline \multirow[b]{2}{*}{ Tekanan Darah Sistole } & \multicolumn{2}{|c|}{ Kelompok } & \multirow[b]{2}{*}{ Nilai p } \\
\hline & $\begin{array}{c}\text { Ketamin } \\
(n=15)\end{array}$ & $\begin{array}{c}\text { Fentanil } \\
(n=15)\end{array}$ & \\
\hline \multicolumn{4}{|l|}{ TDS preinduksi (mmHg) } \\
\hline$M e a n \pm \mathrm{SD}$ & $119,80 \pm 9,088$ & $120,73 \pm 9,059$ & 0,780 \\
\hline \multicolumn{4}{|l|}{ TDS 1 menit (mmHg) } \\
\hline Mean \pm SD & $116,60 \pm 11,562$ & $104,00 \pm 9,943$ & $0,003^{* *}$ \\
\hline \multicolumn{4}{|l|}{ TDS 3 menit (mmHg) } \\
\hline Mean $\pm \mathrm{SD}$ & $116,73 \pm 7,497$ & $99,40 \pm 7,586$ & $0,0001^{* *}$ \\
\hline \multicolumn{4}{|l|}{ TDS 5 menit (mmHg) } \\
\hline Mean \pm SD & $118,73 \pm 8,876$ & $103,00 \pm 6,164$ & $0,0001^{* *}$ \\
\hline \multicolumn{4}{|l|}{ TDS 10 menit (mmHg) } \\
\hline Mean \pm SD & $119,67 \pm 5,900$ & $116,00 \pm 9,993$ & 0,231 \\
\hline
\end{tabular}

Keterangan: nilai kemaknaan berdasar atas nilai $\mathrm{p}<0,05$. Tanda* menunjukkan nilai $\mathrm{p}<0,05$ artinya signifikan atau bermakna secara statistik 
Tabel 3 Perbandingan Tekanan Darah Diastole antara Kedua Kelompok

\begin{tabular}{|c|c|c|c|}
\hline \multirow[b]{2}{*}{ Tekanan Darah Diastole } & \multicolumn{2}{|c|}{ Kelompok } & \multirow[b]{2}{*}{ Nilai p } \\
\hline & $\begin{array}{c}\text { Ketamin } \\
(n=15)\end{array}$ & $\begin{array}{c}\text { Fentanil } \\
(n=15)\end{array}$ & \\
\hline \multicolumn{4}{|l|}{ TDD preinduksi (mmHg) } \\
\hline Mean \pm SD & $56,33 \pm 5,192$ & $56,33 \pm 5,473$ & 1,000 \\
\hline \multicolumn{4}{|l|}{ TDD 1 menit (mmHg) } \\
\hline Mean \pm SD & $52,60 \pm 5,235$ & $49,20 \pm 5,375$ & 0,090 \\
\hline \multicolumn{4}{|l|}{ TDD 3 menit (mmHg) } \\
\hline Mean \pm SD & $52,93 \pm 4,217$ & $48,27 \pm 3,453$ & $0,003^{* *}$ \\
\hline \multicolumn{4}{|l|}{ TDD 5 menit (mmHg) } \\
\hline Mean \pm SD & $54,80 \pm 4,178$ & $48,13 \pm 4,224$ & $0,0001^{* *}$ \\
\hline \multicolumn{4}{|l|}{ TDD 10 menit (mmHg) } \\
\hline Mean $\pm \mathrm{SD}$ & $54,20 \pm 4,178$ & $54,00 \pm 5,196$ & 0,908 \\
\hline
\end{tabular}

Keterangan: nilai kemaknaan berdasar atas nilai $\mathrm{p}<0,05$. Tanda* menunjukkan nilai $\mathrm{p}<0,05$ artinya signifikan atau bermakna secara statistik

Pada variabel nadi 1 menit, nadi 3 menit, dan nadi 5 menit didapatkan laju nadi pada kelompok ketamin lebih cepat dibanding dengan kelompok fentanil dengan perbedaan signifikan $(\mathrm{p}<0,05$; Tabel 4$)$.

Skor pemulihan pascaanestesi yang diukur dengan skor total Qor-40 didapatkan skor total reratakelompok ketaminlebih tinggidibanding dengan kelompok fentanil $(181,07 \pm 5,32 \mathrm{vs}$ $176,60 \pm 2,59)$ dengan perbedaan signifikan $(p<0,05)$. Skor rerata aspek kenyamanan pada kelompok ketamin lebih tinggi dibanding dengan kelompok fentanil dengan perbedaan signifikan $(p<0,05)$, sedangkan skor rerata aspek perasaan, dukungan terhadap pasien, kemandirian, dan nyeri antara kedua kelompok

Tabel 4 Perbandingan Laju Nadi antara Kedua Kelompok

\begin{tabular}{|c|c|c|c|}
\hline \multirow[b]{2}{*}{ Laju Nadi } & \multicolumn{2}{|c|}{ Kelompok } & \multirow[b]{2}{*}{ Nilai p } \\
\hline & $\begin{array}{c}\text { Ketamin } \\
(n=15)\end{array}$ & $\begin{array}{c}\text { Fentanil } \\
(n=15)\end{array}$ & \\
\hline \multicolumn{4}{|c|}{ Nadi preinduksi (x/menit) } \\
\hline Mean $\pm \mathrm{SD}$ & $86,13 \pm 6,010$ & $84,13 \pm 7,259$ & 0,418 \\
\hline \multicolumn{4}{|l|}{ Nadi 1 menit (x/menit) } \\
\hline$M e a n \pm \mathrm{SD}$ & $88,00 \pm 6,887$ & $75,80 \pm 7,466$ & $0,0001^{* *}$ \\
\hline \multicolumn{4}{|l|}{ Nadi 3 menit (x/menit) } \\
\hline Mean \pm SD & $83,13 \pm 6,232$ & $71,73 \pm 7,285$ & $0,0001^{* *}$ \\
\hline \multicolumn{4}{|l|}{ Nadi 5 menit (x/menit) } \\
\hline Mean $\pm \mathrm{SD}$ & $89,27 \pm 7,353$ & $71,87 \pm 7,827$ & $0,0001^{* *}$ \\
\hline \multicolumn{4}{|l|}{ Nadi 10 menit (x/menit) } \\
\hline Mean \pm SD & $88,47 \pm 4,611$ & $85,87 \pm 6,967$ & 0,238 \\
\hline
\end{tabular}

Keterangan: nilai kemaknaan berdasar atas nilai $\mathrm{p}<0,05$. Tanda* menunjukkan nilai $\mathrm{p}<0,05$ artinya signifikan atau bermakna secara statistik. 
Tabel 5 Perbandingan QoR-40 antara Kedua Kelompok

\begin{tabular}{|c|c|c|c|}
\hline \multirow[b]{2}{*}{ Variabel } & \multicolumn{2}{|c|}{ Kelompok } & \multirow[b]{2}{*}{ Nilai p } \\
\hline & $\begin{array}{c}\text { Ketamin } \\
(n=15)\end{array}$ & $\begin{array}{c}\text { Fentanil } \\
(n=15)\end{array}$ & \\
\hline Kenyamanan & & & $0,0001^{* *}$ \\
\hline Mean \pm SD & $54,60 \pm 1,99$ & $51,47 \pm 1,55$ & \\
\hline Perasaan & & & 0,567 \\
\hline Mean $\pm \mathrm{SD}$ & $41,40 \pm 1,20$ & $40,73 \pm 1,10$ & \\
\hline Dukungan terhadap pasien & & & 0,325 \\
\hline Mean $\pm \mathrm{SD}$ & $32,20 \pm 1,37$ & $31,67 \pm 1,35$ & \\
\hline Kemandirian & & & 0,806 \\
\hline Mean $\pm \mathrm{SD}$ & $21,80 \pm 1,21$ & $21,73 \pm 1,10$ & \\
\hline Nyeri & & & 0,267 \\
\hline Mean $\pm \mathrm{SD}$ & $31,47 \pm 1,19$ & $31,00 \pm 1,00$ & \\
\hline Skor Total & & & $0,007^{* *}$ \\
\hline Mean \pm SD & $181,07 \pm 5,32$ & $176,60 \pm 2,59$ & \\
\hline
\end{tabular}

Keterangan: nilai kemaknaan berdasar atas nilai $\mathrm{p}<0,05$. Tanda* menunjukkan nilai $\mathrm{p}<0,05$ artinya signifikan atau bermakna secara statistik

tidak berbeda signifikan ( $p>0,05$; Tabel 5).

\section{Pembahasan}

Subjek penelitian ini terdiri atas 30 pasien dengan karakteristik subjek berdasar atas usia, jenis kelamin, tinggi badan, berat badan, BMI, lama operasi, dan tingkat pendidikan antara kedua kelompok tidak menunjukkan perbedaan bermakna $(p>0,05)$. Hal ini menunjukkan bahwa sampel yang dibandingkan pada penelitian ini homogen dan layak dibandingkan.

Hipotensi setelah induksi anestesi dapat mengakibatkan peningkatan risiko terjadi iskemia miokardium dan sering terjadi pada induksi anestesi yang menggunakan opioid. ${ }^{9}$ Pada pengukuran hemodinamik intraoperasi didapatkan bahwa kelompok yang diinduksi menggunakan ketamin memiliki tekanan darah dan laju nadi yang lebih stabil di menit ke-1, 3, dan 5 setelah induksi bila dibanding dengan kelompok yang diinduksi menggunakan fentanil.

Pada penelitian ini ternyata pasien yang mempergunakan ketamin memperlihatkan perubahan tekanan darah dan laju nadi yang lebih kecil. Hal ini disebabkan oleh ketamin memiliki efek tidak langsung terhadap simpatis pada sinus node dan efek cardiostimulant dari dosis subanestesi ketamin sehingga menyeimbangkan penurunan efek kardiovaskular dari propofol saat induksi. ${ }^{4}$ Pasien yang menggunakan fentanil dan propofol menunjukkan penurunan tekanan darah yang lebih besar disebabkan oleh propofol memiliki efek penurunan tekanan darah akibat penurunan systemic vascular resistance, penurunan preload, dan penurunan kontraktilitas jantung dan fentanil dapat menyebabkan penurunan tekanan darah yang diakibatkan oleh bradikardia, venodilatasi, dan penurunan refleks simpatis. ${ }^{10}$ Namun, secara klinis perbedaan tersebut tidak bermakna karena perubahan tekanan darah dan laju nadi pada kedua kelompok tidak melebihi $20 \%$ dari pengukuran awal.

Wawancara terhadap pasien menggunakan kuesioner QoR-40 dilakukan saat 24 jam pascaoperasi. Pada kuesioner QoR-40 didapatkan 5 aspek utama terkait dengan evaluasi kualitas pemulihan pasien, yaitu 
kenyamanan, perasaan, dukungan terhadap pasien, kemandirian, dan nyeri. Nilai total QoR-40 didapatkan lebih tinggi secara signifikan pada kelompok ketamin dibanding dengan kelompok fentanil dengan perbedaan yang bermakna pada aspek kenyamanan nilai kelompok ketamin lebih tinggi dibanding dengan kelompok fentanil.

Hasil analisis kuesioner pada aspek kenyamanan (mual, muntah, muntah tanpa keluar isi, bernapas dengan mudah, tidur nyenyak, kedinginan, dan pusing) didapatkan tiga hal yang membuat aspek kenyamanan berbeda secara signifikan, yaitu mual, muntah, dan muntah tanpa keluar isi. Kelompok ketamin memiliki skor yang lebih tinggi pada poin mual, muntah, dan muntah tanpa keluar isi. Tidak ada perbedaan poin hasil kuesioner untuk pertanyaan lain di aspek kenyamanan. Hal ini sesuai dengan penelitian yang dilakukan sebelumnya yang menyatakan bahwa penggunaan ketamin mengurangi angka kejadian komplikasi akibat penggunaan opioid intraoperasi, dengan angka kejadian mual pada kelompok fentanil 26,7\%, dan angka kejadian muntah 20\% dibanding dengan angka kejadian mual dan muntah pada ketamin $0 \%{ }^{11}$ Pada penelitian lain dinyatakan bahwa ketamin pada dosis subanestesi $(0,3 \mathrm{mg} /$ kgBB) mengurangi risiko mual dan muntah. ${ }^{12}$ Pada penelitian mengenai penambahan ketamin pada opioid patient-control analgesia pascaoperasi didapatkan bahwa penambahan ketamin untuk analgetik pascaoperasi dapat mengurangi kejadian PONV tanpa efek samping halusinasi. ${ }^{13}$ Hasil ulasan Cochrane menyatakan pengurangan angka kejadian mual dan muntah pascaoperasi pada dosis subanestesi yang kemungkinan dikarenakan efek opioid-sparing. ${ }^{14}$ Opioid sparing effect merupakan efek yang terjadi pada penggunaan analgetik non-opioid tanpa penambahan opioid ataupun yang dikombinasikan dengan analgetik opioid dosis lebih rendah untuk mendapatkan efek analgetik yang sama. Hal ini akan mengurangi paparan pasien terhadap opioid sehingga mengurangi efek samping opioid termasuk mual dan muntah. ${ }^{15}$ Risiko mual dan muntah pascaoperasi dapat dikurangi dengan pemakaian analgetik nonopioid, anestesi/analgesi regional, serta analgesi multimodal. ${ }^{16}$

Mekanisme mual dan muntah pada pemberian opioid dikaitkan kepada stimulasi secara langsung chemoreceptor trigger zone (CTZ) yang terletak pada dasar ventrikel keempat. Pusat muntah yang terdapat di dalam CTZ mengirimkan sinyal melalui eferen autonom dan saraf kranial ke saluran pencernaan bagian atas, diafragma, dan otot abdominal. Secara lebih detail pemberian opioid dalam dosis kecil merangsang reseptor $\mu$ dan $\delta$ pada CTZ yang memproduksi mual. Sementara itu aktivasi reseptor dopamin D2 dan reseptor serotonin 5-HT3 juga merangsang pusat muntah. ${ }^{17}$ Selain itu, opioid menginhibisi motilitas saluran pencernaan dengan mengaktivasi reseptor $\mu$ opioid pada saluran pencernaan. Konstipasi dan distensi dari saluran pencernaan akan menstimulasi mekanoreseptor yang menimbulkan rasa mual. ${ }^{17}$

Post operative nausea and vomiting (PONV) adalah mual atau muntah yang terjadi 24 jam pertama setelah pembedahan. Faktorfaktor yang dapat meningkatkan risiko PONV, yaitu wanita, obesitas, lama operasi $>120$ menit, penggunaan gas anestesi, dan anestesi umum. ${ }^{18}$ Pada penelitian ini kedua kelompok menunjukkan perbedaan tidak bermakna pada faktor-faktor tersebut sehingga tidak ada faktor-faktor lain yang menjadikan bias pada penelitian ini.

Hasil analisis aspek nyeri dari kuesioner tidak didapatkan perbedaan bermakna antara kelompok yang diinduksi menggunakan ketamin dibanding dengan kelompok yang diinduksi menggunakan fentanil. Mekanisme kerja fentanil sebagai analgetik dengan cara berikatan dengan reseptor pada sistem saraf pusat dan jaringan lain. Aktivasi reseptor menghambat neurotransmitter excitatory dari saraf nociceptive. Fentanil bekerja pada transmisi, modulasi, dan persepsi dari jalur nyeri. Ketamin bekerja pada jalur nyeri modulasi dan persepsi dengan cara menghambat efek membran eksitatori neurotransmitter asam glutamat pada subtipe 
reseptor NMDA. ${ }^{10}$ Dengan kesetaraan dosis fentanil dan ketamin yang digunakan pada penelitian ini menghasilkan efek analgetik yang sama. Hal ini serupa dengan penelitian metaanalisis mengenai penggunaan ketamin sebagai alternatif opioid untuk nyeri akut di instalasi gawat darurat, menyatakan bahwa ketamin tidak lebih inferior dibanding dengan opioid untuk mengontrol nyeri. ${ }^{12}$

Hasil analisis kuesioner pada aspek perasaan (mimpi buruk, cemas, bingung pengendalian keadaan, dan sulit tidur), aspek dukungan terhadap pasien (kemampuan memahami arahan, dan berkomunikasi secara baik), dan aspek kemandirian (kemampuan melakukan aktivitas harian) berhubungan dengan pemulihan pascaanestesi umum dan pembedahan tidak berbeda bermakna antara kelompok ketamin dan fentanil.

Ketamin memiliki efek samping yang disebut emergence reaction, yaitu reaksi psikis yang terjadi pada saat pasien bangun setelah pemberian ketamin berupa halusinasi, mimpi buruk, delirium, agitasi, dan perubahan suasana hati yang berpengaruh terhadap penilaian ketiga aspek tersebut. Ketamin memiliki efeksampingyang dapat menurunkan skor pemulihan anestesi pada ketiga aspek, yaitu halusinasi, mimpi buruk, delirium, dan agitasi pada aspek perasaan. Efek samping delirium, agitasi, dan perubahan suasana hati berpengaruh pada aspek dukungan terhadap pasien, sedangkan efek samping ketamin halusinasi, delirium, dan agitasi berpengaruh menurunkan skor pemulihan anestesi pada aspek kemandirian. Pada penelitian ini digunakan dosis ketamin subanestesi $(0,5 \mathrm{mg}$ / kgBB) sehingga efek samping yang muncul berkurang atau minimal.

Fentanil memiliki efek samping timbul nyeri kepala, pusing, dan gangguan tidur. Efek samping ini dapat memengaruhi ketiga aspek yang dinilai, yaitu perasaan, kemandirian, dan dukungan. Pada penelitian ini efek samping fentanil tidak signifikan, hal ini diakibatkan oleh durasi kerja fentanil 30-60 menit. ${ }^{8,10}$

Pada penelitian yang dilakukan sebelumnya didapatkan bahwa pada skor QoR-40 bagian perasaan, kemandirian, dan aspek dukungan terhadap pasien tidak terdapat perbedaan bermakna antara kelompok pasien yang diberikan anestesi TIVA bersama opioid dibanding dengan kelompok pasien yang diberikananestesiTIVA nonopioid padaoperasi ginekologis perlaparoskopik. Hal ini serupa dengan penelitian lain yang mengemukakan bahwa tidak ada perbedaan aspek perasaan, kemandirian, dan dukungan terhadap pasien pada pasien yang menggunakan anestesi nonopioid selama periode perioperatif dibanding dengan kelompok yang menggunakan opioid. 6,19

Keterbatasan penelitian ini tidak tingkat kecemasan pasien preoperasi dan penggunaan kuesioner QoR-40 hanya diukur pada periode 24 jam pascaoperasi sehingga peneliti tidak dapat mengetahui kualitas pemulihan pascaoperasi jangka panjang.

\section{Simpulan}

Skor pemulihan pascaanestesi umum menggunakan ketamin lebih tinggi dibanding dengan fentanil pada operasi odontektomi yang diukur dengan QoR-40. Pada penelitian ini juga pemberian ketamin dosis subanestesi saat induksi menunjukkan hemodinamik yang lebih stabil dibanding dengan induksi menggunakan fentanil.

\section{Daftar Pustaka}

1. Brown EN, Pavone KJ, Naranjo M. Multimodal general anesthesia: theory and practice. Anesth Analg. 2018; 127(5):1246-58.

2. Hontoir S, Saxena, Gatto P, Khalife M, Ben Aziz AM, Paesmans M, Sosnowski M, dkk. Opioid-free anesthesia: what about patient comfort? A prospective, randomized, controlled trial. Acta Anaesthesiol Belg. 2016;67(4):183-90.

3. Gorlin A, Rosenfeld D, Ramakrishna H. Intravenous sub-anesthetic ketamine for perioperative analgesia. J Anaesthesiol Clin Pharmacol. 2016;32(2):160-7.

4. Goyal R, Singh M, Sharma J. Comparison of ketamine with fentanyl as co-induction 
in propofol anesthesia for short surgical procedures. Intern J Crit Ill Injury Sci. 2012;2(1):17-20.

5. Aravena P, Cartes Velásquez R, Rosas C. Signs and symptoms of postoperative complications in third molar surgery: a literature review. J Intern Dental Med Res. 2015;8:140-6.

6. Mulier J, Wouters R, Dillemans B, Dekock M. A randomized controlled, doubleblind trial evaluating the effect of opioidfree versus opioid general anaesthesia on postoperative pain and discomfort measured by the qor-40. J Clin Anesth Pain Med. 2018;2(1):1-6.

7. Alkandari Z, Kind SL, Spahn DR, Biro P. Early post-anaesthesia recovery parameters-a prospective observational study. Romanian J Anaesth Intens Care. 2015;22(2):103.

8. Gornall BF, Myles PS, Smith CL, Burke JA, Leslie K, Pereira MJ, dkk. Measurement of quality of recovery using the qor-40: a quantitative systematic review. $\mathrm{Br} \mathrm{J}$ Anesth. 2013;111(2):161-9.

9. Ongewe A, Mung'ayi V, Bal R. Effect of low-dose ketamine versus fentanyl on attenuating the haemodynamic response to laryngoscopy and endotracheal intubation in patients undergoing general anaesthesia: a prospective, doubleblinded, randomised controlled trial. Afr Health Sci. 2019;19(3):2752-63.

10. Butterworth JF. Intravenous anesthetics. Dalam: Butterworth JF, Mackey DC, Wasnick DJ, penyunting. Morgan \& Mikhail's clinical anesthesiology. Edisi ke6. Philadephia: Lange; 2018. hlm. 175-88.

11. Attalla H, Habeeb R, Elzwedy A. Intravenous infusion of ketamine versus fentanyl for postoperative analgesia in spine surgeries. Menoufia Med J. 2018;31(4):1206-12.

12. Karlow N, Schlaepfer CH, Stoll CRT,
Doering M, Carpenter CR, Colditz GA, dkk. A systematic review and meta-analysis of ketamine as an alternative to opioids for acute pain in the emergency department. Acad Emerg Med. 2018;25(10):1086-97.

13. Assouline B, Tramèr MR, Kreienbühl L, Elia $\mathrm{N}$. Benefit and harm of adding ketamine to an opioid in a patient-controlled analgesia device for the control of postoperative pain: systematic review and metaanalyses of randomized controlled trials with trial sequential analyses. PAIN. 2016;157(12):2854-64.

14. Bell RF, Moore RA, Kalso E. Perioperative ketamine for acute postoperative pain. Cochrane Database Syst Rev. 2006;(1):CD004603.

15. Lapietra A, Motov S. A country in crisis: opioid sparing solutions for acute pain management. Missouri Med. 2019;116:140-5.

16. Kumar K, Kirksey MA, Duong S, Wu CL. A review of opioid-sparing modalities in perioperative pain management: methods to decrease opioid use postoperatively. Anesth Analg. 2017;125(5):1749-60.

17. Mallick-Searle T, Fillman M. The pathophysiology, incidence, impact, and treatment of opioid-induced nausea and vomiting. J Am Assoc Nurs Practition. 2017;29(11):704-10.

18. Lee J, Lee E, Kim Y, Kim E, Lee Y. Effects of gum chewing on abdominal discomfort, nausea, vomiting and intake adherence to polyethylene glycol solution of patients in colonoscopy preparation. J Clin Nurs. 2016;25(3-4):518-25.

19. Hakim K, Wahba W. Opioid-free total intravenous anesthesia improves postoperative quality of recovery after ambulatory gynecologic laparoscopy. Anesth Essays Res. 2019;13:199-203. 